\title{
Engineering Contributions to a Multicultural Perspective of the Knowledge Society
}

\author{
Francisco J. García-Peñalvo \\ Computer Science Department \\ GRIAL Research Group \\ University of Salamanca \\ fgarcia@usal.es
}

\begin{abstract}
Last November 2013, a new Conference about Technological Ecosystems for Enhancing Multiculturality (TEEM) was held at the University of Salamanca, connected with a new PhD Programme about Education in the Knowledge Society. This PhD Programme and the TEEM Conference present an interdisciplinary and multicultural approach to the challenges and solution of problems in the Knowledge Society. Engineering and, more specifically, Software and Computer Engineering play a very outstanding role in this Conference and PhD Programme. We want to thank RITA Journal its support to this project and the opportunity to select a couple of papers from the TEEM Conference to be extended in this issue.
\end{abstract}

Index Terms — Engineering, Multiculturality, Interdisciplinary, Knowledge Society, PhD Programme, TEEM Conference.

\section{INTRODUCTIO}

$\mathrm{W}$ ith the publication of the Spanish Real Decreto 99/2011, January $28^{\text {th }}$, laying down the official Doctoral Degree regulating [1], in the Research Institute for Educational Sciences (IUCE) at the University of Salamanca a new PhD Programme has been defined with an interdisciplinary and multicultural orientation, called "Education in the Knowledge Society" (http:/www.usal.es/webusal/node/30026, http://knowledgesociety.usal.es/) [2]. In this programme several research groups are involved from different subject areas, which are recognized by the University of Salamanca as official research groups: GRIAL (http://grial.usal.es) [3], GITE (http://gite.usal.es/), OCA (http://campus.usal.es/ oca/), VISUALMED (http://visualmed.usal.es/), Robotics and Society Group (http://gro.usal.es/) and E-LECTRA (http://electra.usal.es/), taking into account that GRIAL, GITE and OCA are also Excellence Research Groups of the regional government of Castilla y León (GR47, GR213 and GR319 respectively).

Within the research lines of the PhD Programme, always in cooperation with other research orientations in order to solve complex problems and research challenges of the Knowledge Society, several topics related to engineering appear, such as:

- Interaction and eLearning.

- Robotics in Education.

- Engineering Education.

Through the "Education in the Knowledge Society" PhD Programme, we attempt to qualify future PhDs not only in disciplinary skills, theoretical and practical knowledge or reflection and critical thinking that any PhD Programme would consider as its basic elements: we also want to convey a perspective of addressing and solving complex problems in our current society that may balance both interdisciplinarity and commitment to the Open Knowledge $[4,5]$.

All of this is a reflection of how we think the University should move ahead in order to lead the education and transition to the Knowledge Society [6,7]. At the same time its graduates $(\mathrm{PhDs}$ in this case and therefore alumni with the highest level of training, maturity and leadership) should be able to communicate this perspective to the Society in their professional activity, being amply qualified to combine the formal and informal training received [8-10].

Parallel to the definition of this PhD programme, the International Conference on Technological Ecosystems for Enhancing Multiculturality (TEEM - http://teemconference.eu/) has started, which includes topics that coincide with the Programme's approach and research lines. The conference also has precisely the goal of building an international research community in this area of interest.

Regarding the first edition of this event, TEEM 2013 (http://teemconference.eu/2013) [11, 12], held in Salamanca (Spain) on November 14-16, 2013, two papers have been selected to be extended and, after a new review by the members of the Program 
Committee, have been accepted to be published in the current issue of the IEEE RITA journal (http://rita.det.uvigo.es/).

In the first paper, "Using Robots and Animals as Motivational Tools in ICT Courses", García Sierra et al. present a case study of using robots to improve the interest in robotics among students who are not related to this subject. They have developed a competition that introduces natural and unpredictable elements (living animals, mice in this case) in the environment making these competitions more challenging.

The second paper, "Personal Learning Environments and Online Classrooms: An Experience with University Students", by Humanante Ramos et al., presents an experience of introducing the Personal Learning Environments (PLE) [13] in the higher education context with students of the "Computing Applied to Education" degree at the University of Chimborazo (Ecuador).

\section{ACKNOWLEDGEMENTS}

I want to thank IEEE RITA and its Editor-in-Chief, Dr. Martín Llamas Nistal, the support received in the events that this paper relates.

I also thank the Spanish Ministry of Science and Innovation for the financial support of the TIN2010-21695-C02-01 project, and the Regional Government of Castilla y León region (Spain) throughout the GR47 and MPLE (ref. SA294A12-2) projects.

\section{REFERENCES}

[1] BOE, "Real Decreto 99/2011, de 28 de enero, por el que se regulan las enseñanzas oficiales de doctorado," vol. 35, Ministerio de Educación, Ed., ed. Madrid, Spain: Gobierno de España, 2011, pp. 13909-13926.

[2] F. J. García-Peñalvo, "Formación en la sociedad del conocimiento, un programa de doctorado con una perspectiva interdisciplinar," Revista Teoría de la Educación: Educación y Cultura en la Sociedad de la Información, vol. 15, pp. 4-9, 2014.

[3] F. J. García-Peñalvo, M. J. Rodríguez-Conde, A. M. Seoane-Pardo, M. Á. Conde-González, V. Zangrando, and A. García-Holgado, "GRIAL (GRupo de investigación en InterAcción y eLearning), USAL," IE Comunicaciones. Revista Iberoamericana de Informática Educativa, pp. 85-94, 2012.

[4] F. J. García-Peñalvo, C. García de Figuerola, and J. A. Merlo, "Open knowledge management in higher education," Online Information Review, vol. 34, pp. 517-519, 2010.

[5] F. J. García-Peñalvo, C. García de Figuerola, and J. A. Merlo, "Open knowledge: Challenges and facts," Online Information Review, vol. 34, pp. 520$539,2010$.

[6] A. J. Berlanga, F. J. García-Peñalvo, and P. B. Sloep, "Towards eLearning 2.0 University," Interactive Learning Environments, vol. 18, pp. 199-201, 2010.

[7] F. J. García-Peñalvo, "La Universidad de la próxima década: La Universidad Digital," in Universidad y Desarrollo Social de la Web, C. SuárezGuerrero and F. J. García-Peñalvo, Eds., ed Washington DC, USA: Editandum, 2011, pp. 181-197.

[8] F. J. García-Peñalvo, R. Colomo-Palacios, and M. D. Lytras, "Informal learning in work environments: training with the Social Web in the workplace," Behaviour \& Information Technology, vol. 31, pp. 753-755, 2012.

[9] F. J. García-Peñalvo, M. Á. Conde, V. Zangrando, A. García-Holgado, A. M. Seoane, M. Alier, et al., "TRAILER Project (Tagging, Recognition, Acknowledgment of Informal Learning Experiences). A Methodology to Make Learners' Informal Learning Activities Visible to the Institutions," Journal of Universal Computer Science, vol. 19, pp. 1661-1683, 2013.

[10] F. J. García-Peñalvo, V. Zangrando, A. García-Holgado, M. A. Conde, A. M. Seone Pardo, M. Alier Forment, et al., "TRAILER project overview: Tagging, recognition and acknowledgment of informal learning experiences," presented at the 2012 International Symposium on Computers in Education (SIIE), Andorra La Vella, Andorra. October 29-31, 2012, 2012.

[11] F. J. García-Peñalvo, Proceedings of the First Ynternational Conference on Technological Ecosystem for Enhancing Multiculturality, TEEM 2013. New York, USA: ACM, 2013.

[12] F. J. García-Peñalvo, A. García-Holgado, and I Cruz-Benito, Proceedings of the TEEM'13 Track on Knowledge Society Related Projects. Salamanca, Spain: Grupo GRIAL, 2013.

[13] G. Attwell, "The Personal Learning Environments - The future of eLearning?," eLearning Papers, vol. 2, 2007.

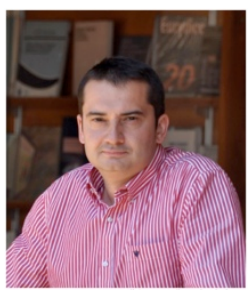

Francisco José García-Peñalvo did his undergraduate studies in Computing at the University of Salamanca and University of Valladolid and his Ph.D. at the University of Salamanca. Dr. García-Peñalvo is the head of the research group GRIAL (Research Group Interaction and eLearning). His main research interests focus on eLearning, Computers \& Education, Adaptive Systems, Web Engineering, Semantic Web and Software Reuse. He has led and participated in over 50 research and innovation projects. He was Vice Chancellor for Innovation at the University of Salamanca between March 2007 and December 2009. He has published more than 300 articles in international journals and conferences. He has been guest editor of several special issues of international journals (Online Information Review, Computers in Human Behaviour, Interactive Learning Environments...). He is also a member of the program committee of several international conferences and reviewer for several international journals. 